\section{Archetypes and ancestors}

\section{Colin Patterson}

Richard Owen: Victorian Naturalist. By Nicolaas A. Rupke. Yale University Press: 1994. Pp. 462. £35.

To most contemporary biologists, Richard Owen (1804-92) is dimly recalled only as a villain, an eminent enemy of Darwin over whom T. H. Huxley won famous victories on Darwin's behalf. Comparative biologists should also know Owen as the originator of the distinction between homology and analogy, still the basis of systematics and the comparative method. And Owen has been in the news for naming Dinosauria, whose sesquicentennial was celebrated in 1991. There is ambiguity here between knave and hero, and ambiguity in Owen's nature and work is an underlying theme in Rupke's book.

There has been no biography of Owen since the conventionally eulogistic Life published by his grandson in 1894. For Rupke the reason is simple: "Owen was systematically written out of Victorian history by Darwin and his followers." Reinstatement has begun only in the past decade*, and has emphasized Owen's role in the context of evolution. Rupke, while reviewing the whole of Owen's career, stresses a different aspect, Owen's "drive for the creation of a national museum of natural history", in which he finds the key to understanding that career. After decades of politicking, Owen succeeded; the British Museum (Natural History) opened in 1881, with Owen (aged 76) its first director. To symbolize twentieth-century evaluation of Owen and the Darwinites, Rupke takes three statues in that museum, contrasting the blackened bronze of Owen's with the snowy marble of Darwin's and Huxley's. Yet there is irony here too. In today's museum (incognito as the "Natural History Museum", in the interests of marketing), visitors find Owen looking down the nave of his cathedral from the head of the stairs, a position he has occupied for 75 years. To get there, he displaced Darwin, unveiled in that position by the Prince of Wales in 1889 (Huxley joined Owen in the main hall in 1900). For most of my life, Darwin and Huxley flanked the main entrance and so were the first objects one encountered, but (in the interests of marketing) they are now tucked away beneath Owen's stairs, flanking a snack bar.

Rupke's book is not a conventional biography. For instance, there are only a couple of casual references to Owen's wife (they were married for almost 40 years) and to his only child (who committed suicide in 1886, "jumping into the Thames, leaving his hat with purse, watch and address card inside it on the bank"). Instead, the book is a series of extended scholarly essays, each covering an aspect of Owen's professional career.

The first two essays are on "Museum Politics". Owen's ambiguity is emphasized here in his need to balance two forces, his patrons among the Oxbridge or

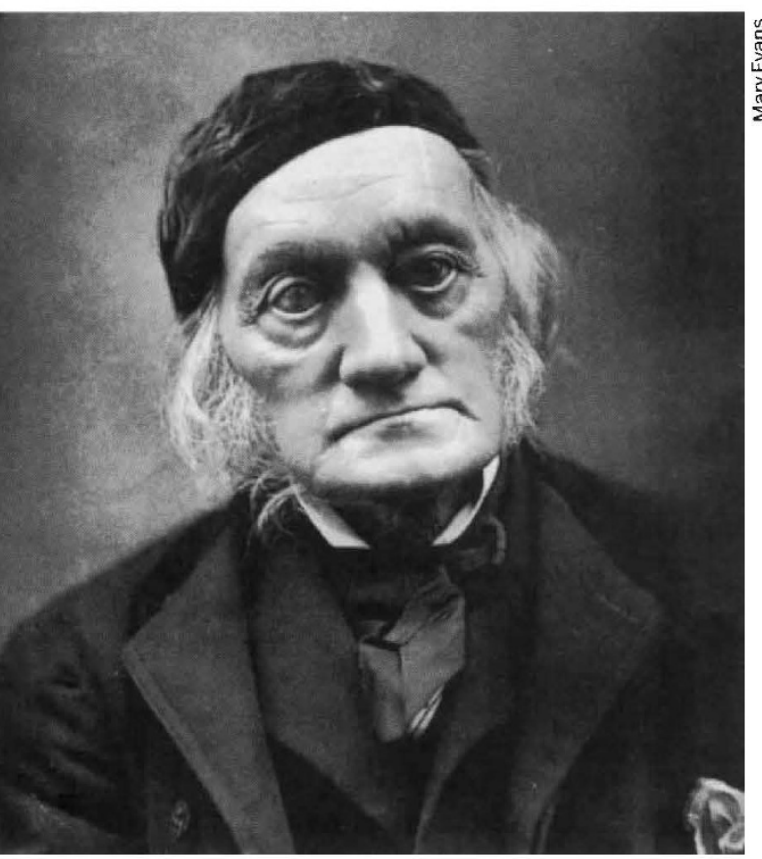

Enigmatic giant - Richard Owen in 1888 .

Oxbridge-educated academic, aristocratic and clerical élite, and his urge to establish a power base in the metropolis, among his professional peers and superiors. Owen's university training was limited to six months at Edinburgh, which, as Adrian Desmond has shown, was the source of most radical theorizing in Victorian scientific London. Owen moved to London in 1825 and "worked his way up through a succession of apprenticeships", primarily in the Hunterian Museum of the Royal College of Surgeons, whence, already laden with honours, he moved to the British Museum in 1856. Owen had previously campaigned to get parts of the museum's collections incorporated in an enlarged Hunterian, as a national museum of comparative anatomy.

Having failed to get the museum to move to him, he moved to it and campaigned there for an independent national museum of natural history. Pressure on space in the Bloomsbury building might be relieved by enlarging it, moving out the natural history collections or moving out the antiquities. The main reason for advocating the last option was the popularity of natural history with the majority of visitors - "the trade- and wage-classes" from the East End, close to Bloomsbury. But the power and tastes of the trustees and the principal librarian, Antonio Panizzi, were enough to maintain antiquities and the library on the central site and relegate natural history to "Albertopolis", the new museum complex that eventually arose in South Kensington, near the site of the Great Exhibition of 1851. Through all these negotiations, which occupied Owen for nearly four decades, Rupke argues that Owen's scientific research was guided by the needs of his museums, primarily for "icons", majestic or rare objects such as the giant extinct reptiles, birds and mammals, or Archaeopteryx (which Rupke consistently spells - pterix, evidently no slip, for the kiwi is also spelt Apterix). These icons attract the visitor, justify spacious premises, symbolize imperial prestige and encourage colonial natural history.

The central third of the book is occupied by two long essays on Owen's scientific work, divided by the themes of function, or Cuvierian method, and form, or the transcendental anatomy of Goethe, Oken and Geoffray. Rupke argues for this division as reconciling Owen's political needs. With functionalism, teleology and the argument from design, he maintained the respect and patronage of Oxbridge clerisy and aristocracy; with transcendentalism he followed his own shifting allegiance towards the science of the continent and his Edinburghtrained metropolitan colleagues, and towards transmutation. Here again, ambiguity is evident; Rupke calls it "the enduring epistemological duality of his oeuvre".

The fifth essay, "Eclipsed by Darwin", shows how, from the mid-1840s, Owen became an evolutionist (covertly supporting Robert Chambers, the anonymous "Vestigiarian", for example), and argues that the impulse came from zoogeography of living and extinct mammals. Yet the ambiguity persists, and although Owen

*Ospovat, D. The Development of Darwin's Theory (Cambridge University Press, 1981); Desmond, A. Archetypes and Ancestors (University of Chicago Press, 1984); Desmond, A. The Politics of Evolution (University of Chicago Press, 1989); Sloan, P. R. (ed.) Richard Owen: The Hunterian Lectures in Comparative Anatomy, May-June 1837 (University of Chicago Press, 1992); Gruber, J. W. \& Thackray, J. C. Richard Owen Commemoration (Natural History Museum Publications, 1992). 
was infuriated by Darwin's counting him among creationists in the Origin, the error can be excused. Owen's wound was repaid in his anonymous review of the Origin, which opened an irreconcilable gulf between him and the Darwinites. The sixth and seventh essays cover the details of one stage in their revenge, the "hippocampus minor controversy" with Huxley over the relationship between man and apes. Huxley, who had been using Owen as a climbing frame for years, outclassed him as tactician and controversialist. The final essay covers minor topics (sea serpents, longevity, vivisection) used by Rupke to show how Owen sought to shift authority from the judiciary (in evidential standards), the clergy (in received wisdom) and the aristocracy (in inherited power) towards science, the real "ministry of truth", and how, once his ambition was achieved and he was installed in his cathedral in South Kensington, he was quite ready to argue against the patrons whom he had courted for so long.

Having spent the greater part of my life in the institution that Owen founded, and having read, used and admired substantial parts of his scientific work, I should be a ready convert to Rupke's "demythologising scholarship". My problem is Owen's prose. Rupke does not mention Owen's work on fishes, my own field. Here he is (in the 1860 textbook on palaeontology) summarizing the history of teleosts: "those species, such as the nutritious cod, the savoury herring, the rich-flavoured salmon, and the succulent turbot, have greatly predominated at the period immediately preceding and accompanying the advent of man; and that they have superseded species which, to judge by the bony Garpikes (Lepisosteus), were much less fitted to afford mankind a sapid and wholesome food". I have never found the prose or the ideas nutritious. Rupke also has trouble with Owen's style ("convoluted, evasive", "the fog of verbal obfuscation", "inimitable prose, resembling an obstacle course"). From the depth and range of his scholarship, Rupke has obviously spent years in Owen's company. Yet he has not come to like the man. At one point he paraphrases Hugh TrevorRoper on Edmund Backhouse: "the mere fact that Owen praised a colleague did not necessarily imply self-glorification". Owen would (anonymously) review his own books and write that he had been "favoured to listen" to his own lectures. I finished the book feeling no closer to understanding Owen the man; he remains an enigmatic giant. He was a great morphologist, but he was also a politician, and as H. L. Mencken put it, a good politician is as unthinkable as an honest burglar.

Colin Patterson is in the Department of Palaeontology, Natural History Museum, London SW7 5BD, UK.

\section{Logic and laws}

\section{Ziauddin Sardar}

The Rise of Early Modern Science: Islam, China and the West. By Toby E. Huff. Cambridge University Press: 1993. Pp. 409. £35, \$54.95.

Islamic Science and Engineering. By Donald Hill. Edinburgh University Press: 1994. Pp. 250. £39.95 (hbk); $£ 16.95$ (pbk).

QUESTIONS, the eleventh-century Muslim philosopher and scientist al-Baruni once said, have meaning only in the worldview and context within which they arise. The most often asked questions about the legacy of al-Baruni, Islamic science, is why it failed to produce a distinctively modern science. Similar questions have been raised about Chinese science. Joseph Needham, among others, has asked: "Given the superiority of Chinese science until the seventeenth century, why did China fail to produce a Galileo?"

Toby Huff sets out to answer these questions. From the eighth to the fourteenth centuries, he tells us, Islamic science was "the most advanced science in the world, greatly surpassing the West and China". Just what the achievements of Islamic science were is described by Donald Hill in his concise and masterly survey, which offers us a new synthesis based on recent research. The starting point for analysing the decline of Islamic science is the mathematical models of the fourteenth-century scientist ibn Shatir, and the work of astronomers at the famous observatory in Maragha, Adharbayjan, built in the thirteenth century by Nasir al-Din al-Tusi. According to Hill, the Maragha astronomers developed the Tusi couple and a theorem for the transformation of eccentric models into epicyclic ones. Copernicus not only used these two basic theorems to build his notion of heliocentricity but also used them at exactly the same points in the model. In other words, the lunar models of Copernicus and the Maragha school are identical. While Hill is concerned with discovering where Copernicus acquired the Maragha theory, Huff asks a much broader question. Why didn't ibn Shatir and his followers at Maragha take the leap to a heliocentric worldview? Why did the Muslims not go the last mile, especially when the Muslims had already taken on Ptolemy some two centuries earlier when ibn alHaytham had boldly declared that "the arrangements proposed for planetary motions in Ptolemy's Almagest were "false"'?

The answers, according to Huff, lie in the religious, sociological and cultural dimensions of the Muslim civilization. The blame rests squarely on Islamic law, Muslim family relationships, the universi- ty system and theological disputes. We are told that because Islamic law "does not recognise corporate personalities" and "the idea of personal liability and the concept of negligence are unknown to Islamic law", cities and universities and other legally autonomous entities could not evolve in the Muslim world. Various schools of legal thought insisted on maintaining their separate identities and principles and therefore aborted the development of universal legal principles. The "extremely personalised nature of human relations" and the dominance of "the traditional extended family" meant that the Muslim civilization was not able to formulate "generalised universal norms". Moreover, "Islamic occasionalism" denied that the laws of nature were governed by a rational order. Also, science was essentially a marginal activity in Muslim civilization: the brilliance of its scientists was an exception to the rule rather than the norm and, in any case, society did not support the scientists, as many of them presented a threat to Islamic theory.

Frankly, Huff's diagnosis is patent nonsense. Islamic law may not recognize "personal negligence" in the sense of European law, but it is based on a much broader notion of individual responsibility and accountability. It does recognize corporate personalities: the wuqfs, the pious trusts and foundations that provided funding for universities, were a type of autonomous corporation. The banality of the suggestion that Islamic occasionalism or any other Islamic 'ism' denies the existence of a rational order defies comprehension. One definition of a Muslim is someone who reflects on and ponders the rational order of the Universe. This is why one-third of all the verses in the Koran are devoted to praising reason and exhorting the believers to use reason. Moreover, it defies all logic, not to say evidence put forward by such scholars as A. I. Sabra, whose arguments are dismissed by Huff with a sleight of hand, to suggest that science was a marginal activity in Islam. Marginal activities are not patronized by caliphs and sultans or supported by a network of magnificent libraries or have scientists and scholars criss-crossing the globe hunting out manuscripts and visiting research institutions. And above all, marginal activities do not take a people to the zenith of civilization.

To substantiate his intangible thesis, Huff systematically presents a totally distorted picture of Islam. We are, for example, told that in Islamic law murder is treated as "a private matter in which the state does not interfere". This will come as news to a billion Muslims across the world. The area in which the "central authority maintains a continuous vigilance", we are told further, is that of "crimes against god, the hudud crimes". As a secondary-school Muslim kid will tell 